Cochrane Database of Systematic Reviews

\title{
Interventions for preventing ankle ligament injuries (Review)
}

Handoll HHG, Rowe BH, Quinn KM, de Bie R

Handoll HHG, Rowe BH, Quinn KM, de Bie R.

Interventions for preventing ankle ligament injuries.

Cochrane Database of Systematic Reviews 2011, Issue 5. Art. No.: CD000018.

DOI: 10.1002/14651858.CD000018.pub2.

www.cochranelibrary.com 
TABLE OF CONTENTS

HEADER 1

REASON FOR WITHDRAWAL FROM PUBLICATION

FEEDBACK

WHAT'S NEW

HISTORY

INDEX TERMS 
[Intervention Review]

\section{Interventions for preventing ankle ligament injuries}

Helen HG Handoll ${ }^{1}$, Brian H Rowe², Kathryn M Quinn ${ }^{3}$, Rob de Bie ${ }^{4}$

${ }_{1}$ Health and Social Care Institute, Teesside University, Middlesborough, UK. 2Department of Emergency Medicine, University of Alberta, Edmonton, Canada. ${ }^{3}$ Department of Psychiatry, Kennedy Tower, 7th Floor, Edinburgh, UK. ${ }^{4}$ Department of Epidemiology, Maastricht University, Maastricht, Netherlands

Contact address: Helen HG Handoll, Health and Social Care Institute, Teesside University, Middlesborough, Tees Valley, TS1 3BA, UK. h.handoll@tees.ac.uk, H.Handoll@ed.ac.uk.

Editorial group: Cochrane Bone, Joint and Muscle Trauma Group.

Publication status and date: Withdrawn from publication for reasons stated in the review, published in Issue 5, 2011.

Citation: Handoll HHG, Rowe BH, Quinn KM, de Bie R. Interventions for preventing ankle ligament injuries. Cochrane Database of Systematic Reviews 2011, Issue 5. Art. No.: CD000018. DOI: 10.1002/14651858.CD000018.pub2.

Copyright @ 2011 The Cochrane Collaboration. Published by John Wiley \& Sons, Ltd.

\section{REASON FOR WITHDRAWAL FROM PUBLICATION}

This review was withdrawn, as of Issue 5, 2011, because it is substantially out-of-date. A new title of the same name has been registered, the protocol for which will be published in 2011.

The editorial group responsible for this previously published document have withdrawn it from publication.

\section{FEE D B A C K}

\section{Request sent 22/5/2000}

\section{Summary}

"I would like to know the exact definition of the terms proprioceptive training, postural control and neuromuscular training."

\section{Reply}

The above comment was considered when updating this review.

\section{Contributors}

Comment sent by Ingeborg Brukken

Reply by Dr Helen Handoll, Edinburgh, UK

Processed by Ms Leeann Morton, Dunedin, New Zealand

Prof Rajan Madhok, Hull, UK (criticisms editor)

\section{WHAT'S NEW}

\begin{tabular}{lll}
\hline Date & Event & Description \\
\hline 31 March 2011 & Amended & Review withdrawn from publication. \\
\hline
\end{tabular}




\section{HISTORY}

Protocol first published: Issue 2, 1996

Review first published: Issue 3, 1997

Date Event Description

13 August 2008 Amended Converted to new review format.

1 April $2001 \quad$ New search has been performed

This review was substantively updated in Issue 3, 2001:

1. Nine new included trials and four new excluded trials have been added.

2. A full report and extra abstract for Amoroso 1998, previously in as Ryan 1994, have been incorporated.

3. A synopsis has been added.

4. Reference is made to a recently available journal review.

5. Active and systematic follow-up has been included in the quality assessment score. The scores have been changed from $3,2,1$ to $2,1,0$.

6 . Peto odds ratios have been altered to relative risks.

In addition, some aspects of review processing were modified reflecting the changes in the circumstances and relative contributions of the review authors. 